\title{
INVESTIGATE OF MICROHARDNESS AND MICROSTRUCTURE OF Ti-Ni-Nb-X (Ta AND V) SHAPE MEMORY ALLOYS
}

\author{
Esra Balci $^{* 1}$ iD, Fethi Dă̆delen ${ }^{1}$ iD \\ ${ }^{I}$ Firat University, Faculty of Science, Department of Physics, Elazig, Turkey
}

\begin{abstract}
Conference paper

In this study, based on designed Ti-50Ni, Ti-27Ni-23Nb, and Ti-27Ni-19Nb-4X (Ta and V) SMAs were prepared using arc melting. The microhardness and microstructure of the prepared alloys were examined. The optical microscope (OM) and Scanning Electron Microscopy (SEM) images can be noted that $\mathrm{Nb}$, Ta, and $\mathrm{V}$ addition in substitution to nickel causes a change in the microstructure morphology of TiNi Shape Memory Alloy at room temperature. The microhardness results shown that when V and Ta elements were added to SMAs, the microhardness of the alloys was significantly increased. Microhardness measurements were determined by taking the alloys from random positions. The microhardness value of equal atomic Ti-Ni SMA was found to $243 \mathrm{HV}_{0.3}$. This value was determined to $354 \mathrm{HV}_{0.3}$ in the Ti-27Ni-23Nb ternary SMA. By the addition of Ta into the Ti-Ni-Nb alloy, the microhardness value was enhanced to approximately 380 $\mathrm{HV}_{0.3}$, additionally, moreover, by adding Vanadium element to the ternary alloy, the microhardness was increased to about $500 \mathrm{HV}_{0.3}$.
\end{abstract}

Keywords: TiNiNbV; TiNiNbTa; shape memory alloy; microhardness; optical microscope.

\section{Ti-Ni-Nb-X (Ta ve V) SSEKIL HATIRLAMALI ALAŞIMLARIN MIKROYAPISI VE MIKROSERTLIKLERININ ARAŞTIRILMASI}

\section{$\ddot{\text { ozet }}$}

Konferans bildirisi

Bu çalışmada hazırlanan Ti-50Ni, Ti-27Ni-23Nb, ve Ti-27Ni-19Nb-4X (Ta ve V) şekil hatırlamalı alaşımlar ark ergitme metodu kullanılarak oluşturuldu. Hazırlanan alaşımların mikrosertlik ve mikroyapıları incelendi. Optik mikroskop ( OM ) ve taramalı elektron mikroskop ( SEM ) görüntüleri, TiNi bazlı şekil hatırlamalı alaşımlara ilave olarak katkılanmış Ta, V ve Nb elementleri ile oda sıcaklığında alınan analizleri ile mikro yapı morfolojilerinde değişiklikler gözlendi. Mikrosertlik sonuçları, şekil hatırlamalı alaşımlara V ve Ta elementleri katkılandığında bu sonuçların değerini artırdığı tespit edilmiştir. Mikrosertlik ölçümleri alaşımlardan rastgele konumlardan alınarak belirlendi. Atomikçe eşit olan Ti-Ni ikili şekil hatırlamalı alaşımlarda bulunan mikrosertlik ölçüm sonucu $243 \mathrm{HV}_{0.3}$ olarak bulundu. Bu değer Ti-27Ni-23Nb üçlü şekil hatırlamalı alaşımlar için $354 \mathrm{HV}_{0.3}$ bulundu. Ti-Ni-Nb alaşımına Ta ilavesi ile mikrosertlik değeri yaklaşık $380 \mathrm{HV}_{0.3}$ ye yükselmiştir. Ayrıca, üçlü şekil hatırlamalı alaşıma V elementi katkılanması sonucunda mikrosertlik ölçüm değeri $500 \mathrm{HV}_{0.3}$ olmuştur.

Anahtar Kelimeler: TiNiNbV; TiNiNbTa; Şekil hatırlamalı alaşım; mikrosertlik; optik mikroskop

\section{Introduction}

"Shape memory" defines the ability to memorize its shape and returning to the original shape of the plastically deformed sample by applying thermomechanical or heat [1-3]. Shape memory alloys (SMAs) have been classified as a type of smart material with different families that are based on a binary alloy. In TiNi alloys, the importance of shape memory alloys has come to light with the shape memory effect $[4,5]$. NiTi-based alloy systems have been studied most extensively and are used in the greatest number of commercial applications. The equiatomic NiTi alloy has superior properties, such as superelasticity [6], high corrosion resistance [7], high fatigue strength, and biocompatibility [8, 9]. These alloys have attracted considerable attention in recent years since they can exhibit wide transformation hysteresis and excellent ductility [1014]. The shape memory effect is a result of the martensitic transformation that occurs in plastically deforming alloy [15]. On the other hand, TiNi alloy has a crystallographic structure that depends on two different temperatures [16]. Such as high-temperature austenite (cubic crystal structure-B2) and lower temperature martensite (monoclinic crystal structure B19/). Because of this reason, 
the microhardness of the other phases may be different in shape memory alloys. It is well known that the microhardness of the austenite phase has higher than the martensite phase in TiNi-based alloys [17]. Moreover, taking into account variations in different temperatures, stress-induced austenite phase to martensite phase transformation may occur during the microhardness test [17]. Many researchers studied how thermo-mechanical treatments can affect the microstructural and crystalline structures of alloys, to manipulate certain mechanical or thermal properties [18]. Moreover, thermomechanical treatment, the effect of aging, and the addition of new elements to form such as ternary or quaternary of the TiNi-based alloy are of great interest [19-21]. Therefore, to improve NiTi alloy, the $\mathrm{Ni}$ concentration can be reduced by replacing it with a third and fourth element, such as Ta, $\mathrm{Nb}, \mathrm{V}, \mathrm{Sn}$. Mareci et al. reported that the substituting of $\mathrm{Ni}$ with $\mathrm{Nb}$ in $\mathrm{NiTiNb}$ alloy increased the resistance of $\mathrm{NiTi}$ shape memory alloy to localized corrosion [22]. In another study, Balci et al. found that the dendritic microstructure of the shape memory alloys prepared in different proportions were different in terms of composition, e.g., although $\mathrm{Ti}$ element has a higher ratio, from the EDX analysis and SEM images showed that the dendritic structure observed of in the Ni27Ti50Nb21V2 (at.\%) alloy almost consist of $\mathrm{Nb}$ [23]. Although the thermal and microstructural properties of Ni-Ti-based alloys have been studied in large numbers in literature, there are almost no studies on the microhardness properties of NiTiNb-4Ta and $\mathrm{NiTiNb}-\mathrm{V} 4$ SMAs.

This study aims to compare the microhardness and OM and SEM images of TiNi, TiNiNb, and TiNiNb-X (X =V or Ta). The alloys were produced by an arc-melting method and in the same environmental conditions. Microhardness; $\mathrm{OM}$ and SEM images of these alloys were examined.

\section{Experimental Procedure}

$\mathrm{Ti}, \mathrm{Ni}, \mathrm{Nb}, \mathrm{Ta}$, and $\mathrm{V}$ powder, with high purity $(99.9 \%)$, elements were used for preparing five different blended by a mechanical mixer. Three different ratios of these powders were chosen to prepare $\mathrm{Ni}_{27} \mathrm{Ti}_{50}$ (named F1), $\mathrm{Ni}_{27} \mathrm{Ti}_{50} \mathrm{Nb}_{23}$ (named F2), $\mathrm{Ni}_{27} \mathrm{Ti}_{50} \mathrm{Nb}_{19} \mathrm{Ta}_{4}$ (named F3), and $\mathrm{Ni}_{27} \mathrm{Ti}_{50} \mathrm{Nb}_{219} \mathrm{~V}_{4}$ (named $\mathrm{F} 4$ ). These compositions with powder materials were pressed under $5 \times 10^{3} \mathrm{~kg}$-force to become disk pellets. They were taken by arc-melting device and then argon was added to the chamber to avoid oxidation. Samples for microscopic observation were mechanically polished and chemically etched in a solution of $\left(\mathrm{HF}+\mathrm{NOH}_{3}+\mathrm{H}_{2} \mathrm{O}: 1: 2: 5\right)$ for approximately $5 \mathrm{sec}$. The microstructures were observed by optic Microstructure Clemex Software-Nikon Eclipse MA200 and by Scanning Electron Microscopy-Energy Dispersive X-ray Spectroscopy (SEM-EDX) device. The microhardness was measured for 10 seconds under $300 \mathrm{~g}$-force load using Durascan Emcotest 20 model microhardness tester. The average of five measurements taken was evaluated for the microhardness test.

\section{Results and Discussion}

Firstly, the percentage (at \%) contents and coding of the shape memory alloys prepared for this study are shown in Table 1. More than one method can be found in the literature for Microhardness test analysis of materials. There are three principal standard test methods for expressing the relationship between hardness. These methods; Brinell, Rockwell, and Vickers [17]. In this study, the microhardness test of the shape memory alloys was made using Vickerss hardness measurement method and it was obtained from five different regions by Duramin Microhardness tester (Struers, Denmark) with a load of 30 $\mathrm{g}$ for $10 \mathrm{~s}$. Microhardness measurements were determined by taking the alloys from random positions. The average microhardness results of the alloys are given in Table 2 .

Table 1. The atomic and weight composition of alloys prepared by arcmelting method.

\begin{tabular}{|c|c|c|c|c|c|c|c|c|c|c|}
\hline \multicolumn{6}{|c|}{ Concentration (at.\%) } & \multicolumn{5}{|c|}{ Concentration (wt.\%) } \\
\hline Samples & $\mathbf{T i}$ & $\mathbf{N i}$ & $\mathbf{N b}$ & $\mathbf{T a}$ & $\mathbf{V}$ & $\mathbf{T i}$ & $\mathbf{N i}$ & $\mathbf{N b}$ & Ta & $\mathbf{V}$ \\
\hline F1 & 50 & 50 & - & - & - & 55.1 & 44.9 & 0 & 0 & 0 \\
\hline F2 & 50 & 27 & 23 & - & - & 25.9 & 39.1 & 34.9 & 0 & 0 \\
\hline F3 & 50 & 27 & 19 & 4 & - & 37.1 & 24.4 & 27.3 & 11.2 & 0 \\
\hline F4 & 50 & 27 & 19 & - & 4 & 40.2 & 26.7 & 29.7 & 0 & 3.4 \\
\hline
\end{tabular}

Table 2. The atomic and weight composition of alloys prepared by arcmelting method.

\begin{tabular}{|lcl|}
\hline Sample & $\begin{array}{l}\text { Microhardness } \\
\left(\boldsymbol{H} \boldsymbol{V}_{\mathbf{0 . 3}}\right)\end{array}$ & $\begin{array}{l}\text { Standard } \\
\text { Deviation }\end{array}$ \\
\hline \hline F1 & 243 & 3 \\
F2 & 354 & 1 \\
\hline \hline F3 & 394 & 3 \\
\hline \hline F4 & 508 & 21 \\
\hline
\end{tabular}

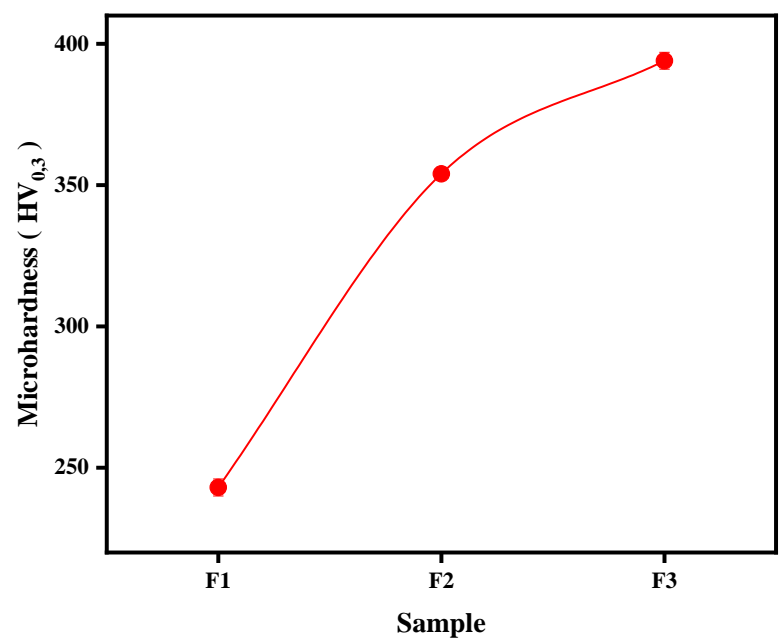

Figure 1. Microhardness measurement of NiTi based and addition different ration $\mathrm{Nb}(19 \%$ at.) and $\mathrm{Ta}$ (4\%at.) elements.

When Table 2 examined, microhardness measurement results have increased as a result of different elements added to NiTi SMAs.

Figure 1 shows the microhardness measurement of NiTi-based and addition different ration $\mathrm{Nb}(\%$ 19) and $\mathrm{Ta}$ (\%4) elements. According to these results, adding by $\mathrm{Nb}$ element and the added Ta element at the rate of 4 percent 
increased the microhardness. The average microhardness measurement results were found to be $243 \mathrm{HV}_{0.3}$ in Ni50Ti50, $354 \mathrm{HV}_{0.3}$ in Ni27Ti50Nb23 ternary SMA. In another study, it was determined that the Sn element added to NiTi-based shape memory alloys in different proportions changed between $180-455 \mathrm{HV}$ as a result of microhardness [24]. Also, in a study by C.Tatar et al., $\mathrm{NiTiCu}$ found to the microhardness measurement results of the shape memory alloy between approximately 200-500 $\mathrm{HV}_{0.3}$ [25]. Figure 2 illustrates the microhardness results of $\mathrm{Ni}-50 \mathrm{Ti}, \mathrm{Ni}-50 \mathrm{Ti}-23 \mathrm{Nb}$, and $\mathrm{Ni}-50 \mathrm{Ti}-19 \mathrm{Nb}-4 \mathrm{~V}$ shape memory alloys. The microhardness measurement result of the $\mathrm{V}$ element with 4 percent contribution was found to be $508 \mathrm{HV}_{0.3}$ on average. When element $\mathrm{V}$ was added to $\mathrm{NiTiNb}$ alloy, it was determined that its microhardness was the highest.

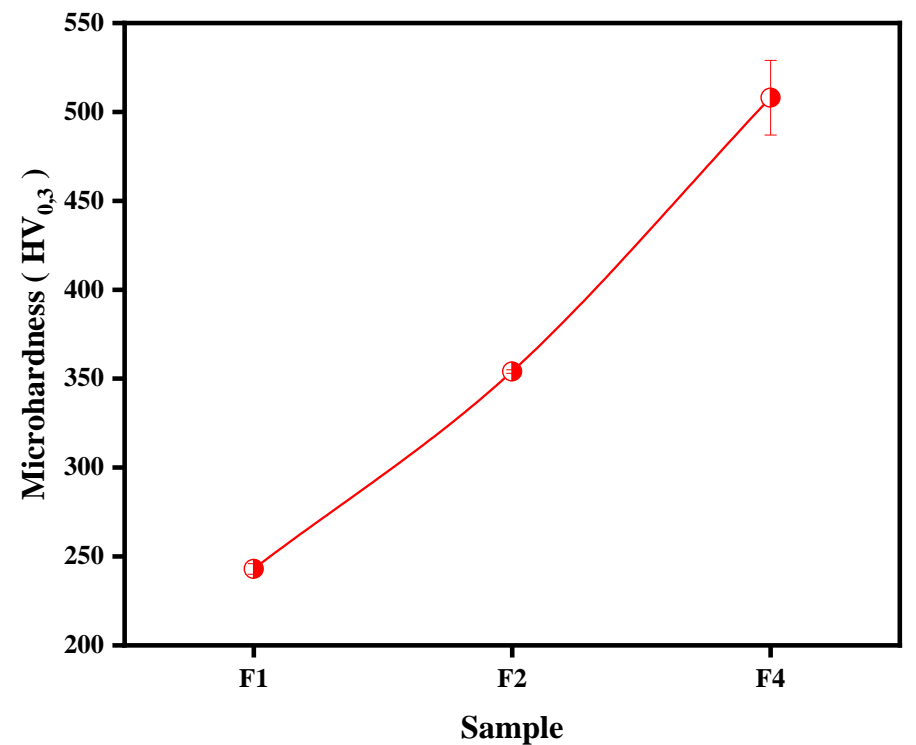

Figure 2. Microhardness measurement of NiTi based and addition different ration Nb (19\%at.) and Ta (4\%at.) elements.
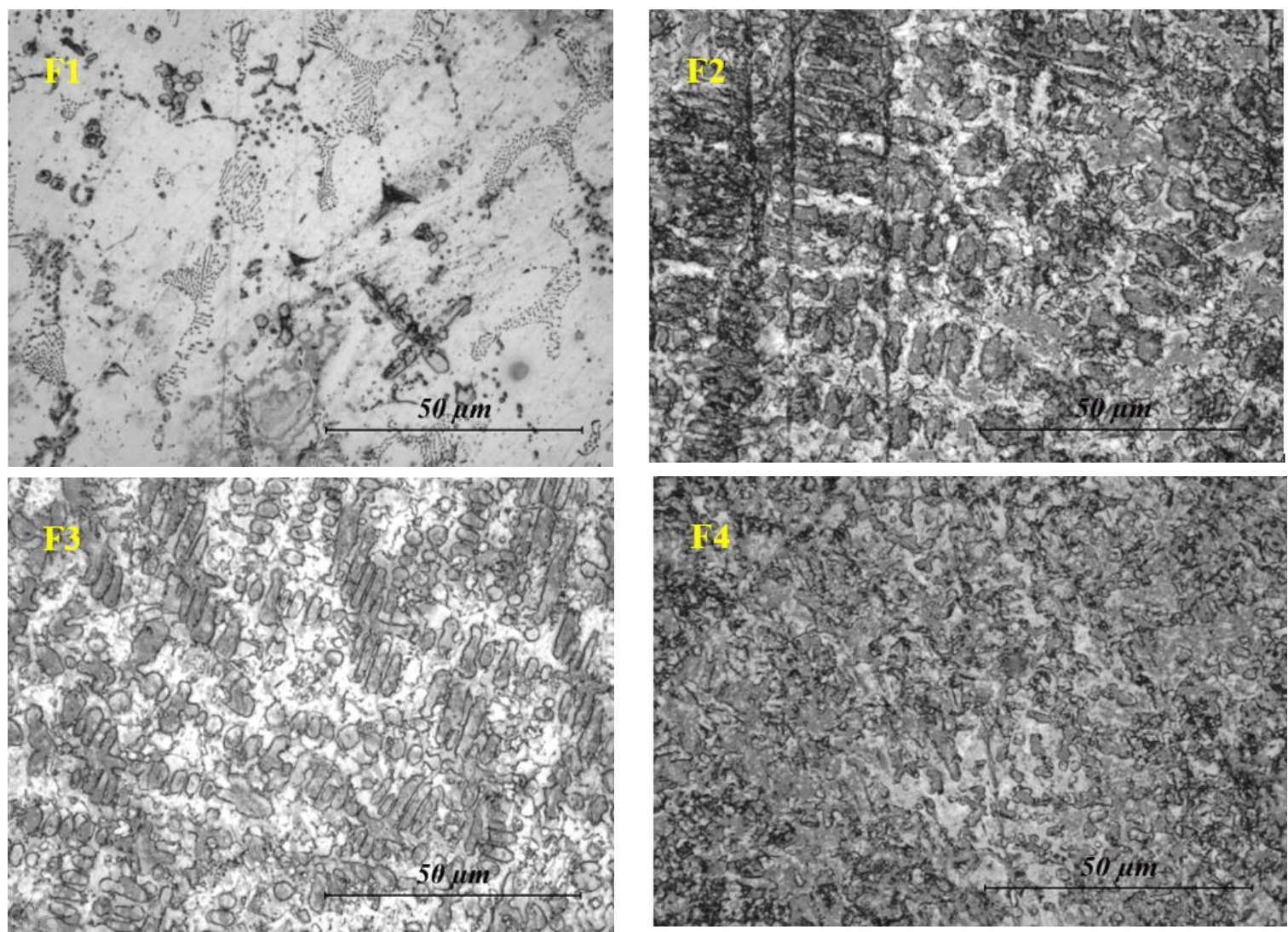

Figure 3. Optical microscope images of shape memory alloys.

Optical microstructure of NiTi shape reminder alloys is given in Figure 3 and its SEM view is given in Figure 4. The optical microstructure of the shape memory alloy with $\mathrm{Ni}$ and $\mathrm{Ti}$ elements shows that the NiTi main structure is an irregular microstructure (sample F1). The NiTiNb SMA (sample F2) structure produced by adding $\mathrm{Nb}$ to the structure performed a more regular dendritic solidification than the sample without $\mathrm{Nb}$ addition. It is clear that solidification occurs with the effect of the fourth element such as $\mathrm{Ta}$ and $\mathrm{V}$ on the structure with a much finer and 
smooth formation compared to the dendritic formation mechanism, as in the F3 and F4 samples. Furthermore, as can be seen in Figure 3 and Figure 4, primary dendritic arms are quite long in F2 and F3 samples. According to the EDS result, the primary dendrite arm is solidified with elements of at.63.19Nb\%, at.32.63Ti, and the remainder Ni. The primary dendrite arm in the Ta added microstructure consisted of the elements at.56.89Nb, at.33.21\% $\mathrm{Ti}$ at. It can be seen in the optical and SEM microstructure in Figure 3 and Figure 4 that it achieves a finer and homogeneous dendritic solidification with the effect of the Ta element. However, the structure of NiTiNbV SMA was quite different from other samples. Matrix structure $57.88 \% \mathrm{Ti}, 31.21 \% \mathrm{Ni}, 5.55 \% \mathrm{Nb}$ and $5.36 \% \mathrm{~V}$ (at.) secondary phase $44.22 \% \mathrm{Ti}, 37.99 \% \mathrm{Ni}$, $13.28 \% \mathrm{Nb}$ (at.). It exhibited solidification from the 4,50V elements. It can be seen in Figure 2 that the secondary phases in the F4 sample, which exhibit a fairly homogeneous structure, also positively affect the mechanical properties of the shape memory material.
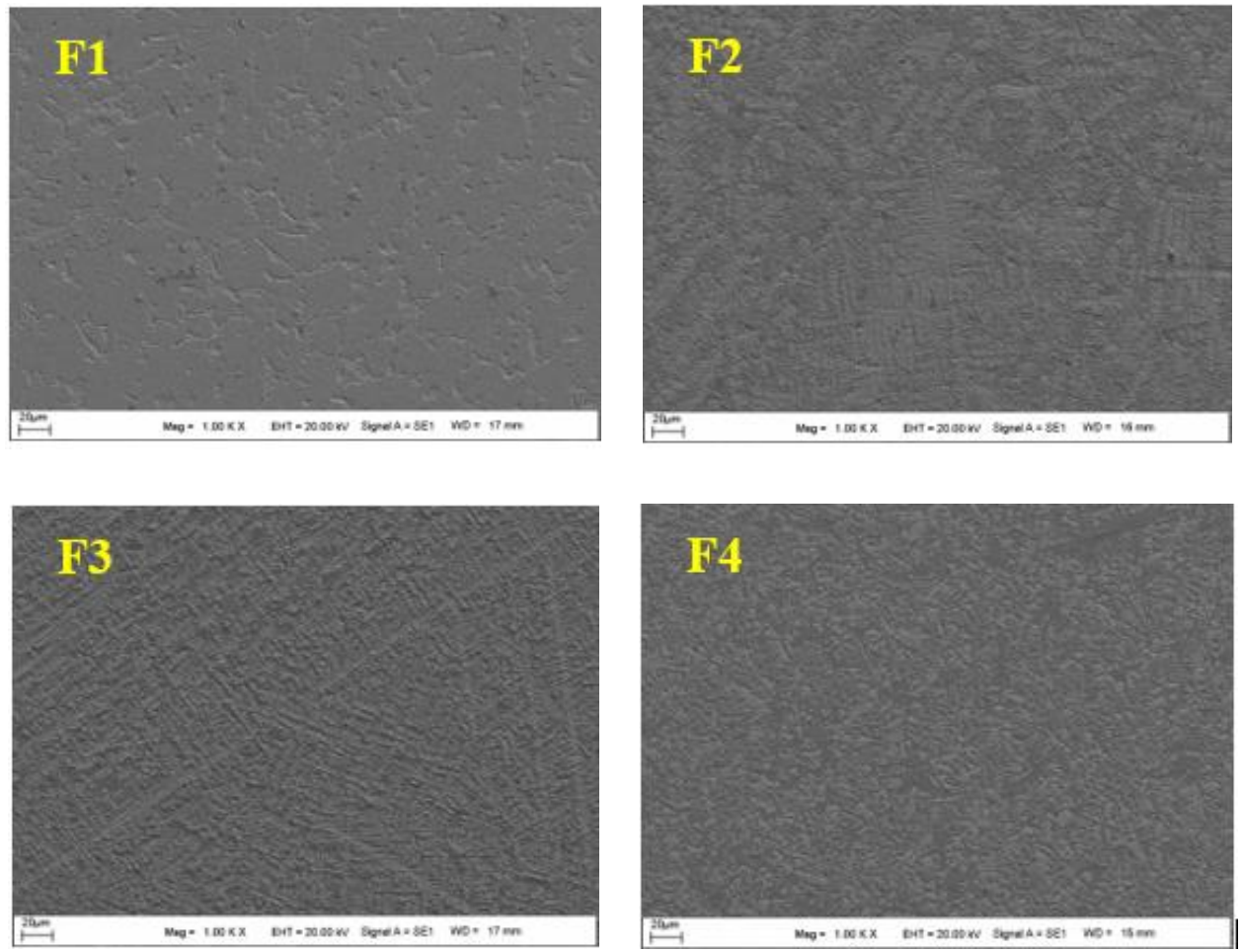

Figure 4. SEM images of shape memory alloy.

\section{Conclusion}

According to the obtained in NiTi-based shape memory alloys prepared, the main outcomes are as follows:

- $\quad$ Adding $\mathrm{Nb}, \mathrm{Ta}, \mathrm{V}$ elements to NiTi shape memory alloys increases the micro-hardness of alloy.

- When the microhardness measurement results of NiTiNb-4Ta and NiTiNb-4V shape memory alloys are compared, the NiTiNb-4V SMA has a high microhardness.

- The surface morphology analysis shows that the NiTiNb, NiTiNbTa, and NiTiNbV SMAs consist of irregular dendritic forms. The dendritic solidification of the alloys changes the mechanical properties of the alloy and increases its microhardness.

- The dendrite arms of NiTiNb based alloys consist of $\mathrm{Nb}$-rich structure phase.

\section{Declaration}

This study titled "Investigate of Microhardness and Microstructure of Ti-Ni-Nb-X (Ta and V) Shape Memory Alloys" was presented at PCFM 2021. study.

Ethics committee approval is not required for this

\section{References}

[1] Stöckel, D. (1995). The shape memory effect-phenomenon, alloys and applications. California, 94539, 1-13.

[2] Sathiya, P., \& Ramesh, T. (2017). Experimental investigation and characterization of laser welded NiTinol shape memory alloys. Journal of Manufacturing Processes, 25, 253-261.

[3] Jani, J. M., Leary, M., Subic, A., \& Gibson, M. A. (2014). A review of shape memory alloy research, applications and opportunities. Materials \& Design (1980-2015), 56, 10781113.

[4] Buehler, W. J., Gilfrich, J. V., \& Wiley, R. C. (1963). Effect of low-temperature phase changes on the mechanical properties of alloys near composition TiNi. Journal of applied physics, 34(5), 1475-1477.

[5] Kauffman, G. B., \& Mayo, I. (1997). The story of nitinol: the serendipitous discovery of the memory metal and its applications. The chemical educator, 2(2), 1-21.

[6] Zhao, D., Guo, Y., Jiang, K., \& Zhang, H. (2017). Preparation and selective laser sintering of bamboo flour/copolyester composite and post-processing. Journal of Thermoplastic Composite Materials, 30(8), 1045-1055. 
[7] Richman, R. H., Rao, A. S., \& Hodgson, D. E. (1992). Cavitation erosion of two NiTi alloys. Wear, 157(2), 401407.

[8] Kaya, I., Tobe, H., Karaca, H. E., Acar, E., \& Chumlyakov, Y. (2016). Shape memory behavior of [111]-oriented NiTi single crystals after stress-assisted aging. Acta Metallurgica Sinica (English letters), 29(3), 282-286.

[9] Wu, S. K., Lin, H. C., \& Yeh, C. H. (2000). A comparison of the cavitation erosion resistance of TiNi alloys, SUS304 stainless steel and Ni-based self-fluxing alloy. Wear, 244(12), 85-93.

[10] Sui, J. H., Gao, Z. Y., Li, Y. F., Zhang, Z. G., \& Cai, W. (2009). A study on NiTiNbCo shape memory alloy. Materials Science and Engineering: A, 508(1-2), 33-36.

[11] Piao, M., Miyazaki, S., \& Otsuka, K. (1992). Characteristics of deformation and transformation in Ti44Ni47Nb9 shape memory alloy. Materials Transactions, JIM, 33(4), 346353.

[12] Zhang, C. S., Zhao, L. C., Duerig, T. W., \& Wayman, C. M. (1990). Effects of deformation on the transformation hysteresis and shape memory effect in a Ni47Ti44Nb9 alloy. Scripta Metallurgica et Materialia, 24(9), 18071812.

[13] Zhang, C. S., Wang, Y. Q., Chai, W., \& Zhao, L. C. (1991). The study of constitutional phases in a Ni47Ti44Nb9 shape memory alloy. Materials Chemistry and Physics, 28(1), 4350.

[14] He, X. M., Rong, L. J., Yan, D. S., \& Li, Y. Y. (2005). Temperature memory effect of Ni47Ti44Nb9 wide hysteresis shape memory alloy. Scripta materialia, 53(12), 1411-1415.

[15] Otsuka, K., \& Wayman, C. M. (Eds.). (1999). Shape memory materials. Cambridge university press.

[16] Bradley, T. G., Brantley, W. A., \& Culbertson, B. M. (1996). Differential scanning calorimetry (DSC) analyses of superelastic and nonsuperelastic nickel-titanium orthodontic wires. American Journal of Orthodontics and Dentofacial Orthopedics, 109(6), 589-597.
[17] Elahinia, M. H. (2016). Shape memory alloy actuators: design, fabrication, and experimental evaluation. John Wiley \& Sons.

[18] Dagdelen, F., Kok, M., \& Qader, I. N. (2019). Effects of Ta content on thermodynamic properties and transformation temperatures of shape memory $\mathrm{NiTi}$ alloy. Metals and Materials International, 25(6), 1420-1427.

[19] Kök, M., \& Ateş, G. (2017). The effect of addition of various elements on properties of NiTi-based shape memory alloys for biomedical application. The European Physical Journal Plus, 132(4), 1-6.

[20] Chluba, C., Ge, W., de Miranda, R. L., Strobel, J., Kienle, L., Quandt, E., \& Wuttig, M. (2015). Ultralow-fatigue shape memory alloy films. Science, 348(6238), 1004-1007.

[21] Aboutalebi, M. R., Karimzadeh, M., Salehi, M. T., Abbasi, S. M., \& Morakabati, M. (2015). Influences of aging and thermomechanical treatments on the martensitic transformation and superelasticity of highly Ni-rich Ti-51.5 at.\% Ni shape memory alloy. Thermochimica Acta, 616, 1419.

[22] Mareci, D., Chelariu, R., Cailean, A., \& Sutiman, D. (2012). Electrochemical characterization of Ni47. 7Ti37. 8Nb14. 5 shape memory alloy in artificial saliva. Materials and Corrosion, 63(9), 807-812.

[23] Balci, E., Dagdelen, F., Qader, I. N., \& Kok, M. (2021). Effects of substituting $\mathrm{Nb}$ with $\mathrm{V}$ on thermal analysis and biocompatibility assessment of quaternary NiTiNbV SMA. The European Physical Journal Plus, 136(2), 1-13.

[24] Qader, I. N., Kok, M., \& Cirak, Z. D. (2021). The effects of substituting $\mathrm{Sn}$ for $\mathrm{Ni}$ on the thermal and some other characteristics of NiTiSn shape memory alloys. Journal of Thermal Analysis and Calorimetry, 145(2), 279-288.

[25] Tatar, C., Acar, R., \& Qader, I. N. (2020). Investigation of thermodynamic and microstructural characteristics of $\mathrm{NiTiCu}$ shape memory alloys produced by arc-melting method. The European Physical Journal Plus, 135(3), 1-11 